\title{
A Informação como Apoio da Ação Administrativa
}

\author{
BENEDICTO SILVA \\ Diretor do Instituto de \\ Documentação da F.G.V.
}

\section{INTRODUÇÃO}

Advirta-se, ab initio: o tema versado neste ensaio está longe de ser polêmico. Com efeito, quem se abalançaria a questionar a importância do papel desempenhado pela informação no processo administrativo?

Vários e complexos ingredientes são mobilizados e combinados pelo homem para administrar, isto é, para transformar planos e projetos em coisas concretas.

Limitada em itens, fácil de ser entendida, flexível na utilização, universal no alcance, prestando-se a tôdas as combinações possíveis, a lista dos meios administrativos, corpóreos e incorpóreos, assemelha-se à escala musical.

Com as sete notas da escala musical, Bach compôs 295 cantatas, 48 prelúdios e fugas e 37 obras diversas. Beethoven, combinando as mesmas sete notas, compôs, além de 54 sonatas e 9 sinfonias, mais 183 pecas diversas. Ambos criaram mundos infinitos de beleza sonora, que ocupam lugares à parte e culminantes no patrimônio artístico da humanidade.

Similarmente, os meios administrativos são passíveis das mais ricas e imprevistas combinaçôes e dosagens. Com êles, os grandes administradores constroem catedrais, universidades, palácios, arranha-céus, hospitais, jardins, portos, rodovias, ferrovias, viadutos; perfuram túneis; abrem canais; combatem e erradicam endemias; educam gerações, aceleram o progresso social e o desenvolvimento econômico; protegem o indivíduo e a família; elevam os padrões de vida; em suma, conduzem povos e dilatam civilizações.

Dentre os meios administrativos conhecidos, aquêle que, nesta espiral do progresso tecnológico, se apresenta em galope mais acelerado para o apogeu é a informação.
Tão importante é o concurso da informação para a produtividade e a racionalidade do processo administrativo, que o enunciado do tema dêste ensaio A informação como apoio da ação administrativa - soa como uma espécie de flagrante subestimativa. A informação não funciona apenas como base, mas sobretudo como centelha detonadora, inspiração, guia e protetor da ação administrativa.

E o que tentaremos demonstrar no curso do presente escrito. E creiam que não se trata de tarefa difícil. Qualquer pessoa capaz de entender a evidência imanente das coisas será igualmente capaz de desempenhar a contento a tarefa de discorrer sôbre o que a informação significa para o administrador. Basta usar o bom senso.

\section{INFORMAÇÃO}

Ad introitum, parece-nos tópico exumar, dentre os milhares de aforismos jurídicos latinos, aquêle que afirma: definitio est initium omni disputationi, a definição é o princípio para tôda disputa.

Mas, a regra de ouro do debate foi ditada por Voltaire. Dizia o autor de Candide: "Se queres discutir comigo, define os têrmos".

Além de espirituosa, a regra de Voltaire tem muito mais sabor e maior fôrça expressiva do que o citado aforismo latino. Acatemo-la, pois.

Que é informação? A fim de metodizar a resposta, focalizamos o conceito de informação sob diferentes aspectos. Considerada em estado natural, como uma gôta d'água sob inspeção microscópica, informação é sinônimo de mensagem, aviso, esclarecimento ou noção, que transita, sob diversas modalidades visuais, sonoras, tácteis, olfativas e gustativas - do informante para o informado. Em outras palavras: a chegada 
ou recebimento de uma informação engaja um, dois, ou mais dos cinco sentidos.

Quando transmitida em condições normais - qualquer que seja o veículo utilizado para a transmissão e qualquer que seja a modalidade preferida ou convencionada - a informação chega, sem maiores obstáculos, ao destinatário. Encontrando-se em estado de vigília e no gôzo pleno de todos os sentidos e da inteligência, o recipiendário não terá dificuldade alguma em captá-la.

Se inteligível e desconhecida, a informação captada tende a enriquecer o fundo de conhecimentos, ou a ampliar o cabedal de experiência do informado.

As informações mais freqüentes nas relações humanas são as visuais e as sonoras. As visuais dividem-se em gráficas, fotográficas, luminosas, coloridas, gesticulares, mecânicas e semafóricas. As sonoras compreendem tôda a gama dos sons audiveis.

Dentre os numerosos meios visuais de comunicar a informação, vale citar um dos mais primitivos - o uso do fogo e da fumaça. O registro mais vetusto da informação comunicada por meio do fogo e da fumaça encontra-se no Exodo, segundo livro do Antigo Testamento. Refere o texto da Bíblia que, na fuga do Egito, os israelitas eram guiados através do deserto, de dia por uma "coluna de nuvem", e de noite por uma "coluna de fogo". "Nunca a coluna de nuvem deixou de preceder o povo durante 0 dia, nem a coluna de fogo durante a noite." De sorte que os fugitivos "podiam marchar de dia e de noite".

Em época mais recente, os índios americanos acendiam fogueiras em montes elevados e comunicavam-se por meio de fumaça, telegrafando informações, de umas a outras tribos, através de distâncias relativamente longas. Seu sistema de smoke-signalling tornou-se largamente conhecido no mundo civilizado, graças aos inúmeros filmes de Far West, em que a cena reproduz aspectos reais ou imaginários das lutas havidas entre o índio invadido e o branco in-
vasor.

Mas, é a Igreja Católica Apostólica Romana que nos oferece a ilustração mais espetacular e engenhosa do emprêgo da fumaça como veículo de informação de importância transcendental. Trata-se da eleição do Papa.
De acôrdo com fonte autorizada (2), - Papa Gregório X decretou, em 1274, no Segundo Concílio de Leão, que a eleição do Papa deveria fazer-se dentro de dez dias, durante os quais não poderia haver comunicação de espécie alguma entre pessoa estranha e os cardeais eleitores. Com as modificações introduzidas por vários Papas, especialmente por Gregório XV, através da Constituição Aeterni Patris (1621), e por Pio X, através da Constituição Vacante Sede Apostolica, o sistema decretado por Gregório X, em 1274, para regular a eleição do Papa, ainda está em vigor. A Igreja Católica é eminentemente conservadora.

Quando a Sede Apostolica se encontra vacante, os cardeais eleitores reúnem-se no Vaticano, isolam-se do mundo, concentram-se na eleição do nôvo Papa. Os votos são dados mediante a inscrição do nome do candidato em uma cédula. Terminada cada votação, as cédulas são contadas e queimadas. E nesse momento que se utiliza a fumaça para transmitir uma informação esperada com grande ansiedade. De que modo? A resposta encontra-se na Encyclopaedia Britannica ${ }^{3}$ ). Imediatamente após a contagem, as cédulas (votos) incineradas produzem fumaça que, "subindo por um cano de ferro através de uma janela, habilita a multidão reunida na Praça de São Pedro a acompanhar o desenvolvimento da votação". Quando nenhum candidato recebe a maioria de votos exigida (dois terços mais um), as cédulas são queimadas juntamente com palha molhada então o cano lança fumaça negra. Quando é eleito o Papa, as cédulas são queimadas de mistura com palha sêca: então o cano anuncia o fato ao mundo, urbi et orbi, soltando fumaça branca.

possível até mesmo utilizar a ausência completa de informação como informação, desde que se proceda de acôrdo com determinado código. Apesar de pertencer ao repertório da chamada $\mathrm{Sa-}$ bedoria Popular, o ditado francês Pas de nouvelles, bonnes nouvelles, tende a corroborar essa afirmativa.

Quanto ao grau de fidedignidade, qualquer informação se enquadra em uma das três categorias, que iluistramos a seguir.

Se verdadeira, completa e precisa, a informação é sinônimo de conhecimento comprovado e documentado. Exemplo: uma tonelada métrica corresponde a 1.000.000 de gramas. 
Se verdadeira, mas incompleta ou imprecisa, a informação confunde-se com aquilo a que se poderia chamar meiaverdade. Exemplo: o quintal métrico designa um pêso algumas dezenas de quilogramas superior ao pêso antigo, de 4 arrôbas (128 a rrát e is ), denominado quintal.

Se falsa, a informação é sinônimo de mentira, equívoco, ardil, ou embuste. Exemplo de informação inverídica: o Japão é o décimo país do mundo, tanto em extensão territorial quanto em população.

Nada obstante, em qualquer dessas situações, a informação "é uma espécie de matéria-prima abstrata", conforme diz Philippe Dreyfus. (4) De fato, ao lado das matérias-primas corpóreas, a informação-conhecimento, ou a informação-experiência, ou ambas, estão presentes e desempenham papel irrecusável em todos os comportamentos humanos.

No sentido específico em que usamos o têrmo neste ensaio, informação deve ser entendida como uma parcela de conhecimento elaborado, verificado, fidedigno, classificado e ordenado, que se transmite por meio de qualquer sistema convencional (ou convencionado) de comunicação: linguagem escrita ou falada, notas musicais, fórmulas matemáticas, sinais semafóricos, g e stos, sons, luzes, côres etc.

Como parcela do conhecimento elaborado e documentado, a informação, embora disponível, enquanto jaz inconsultada nas bibliotecas, nos fichários ou em quaisquer coleções de documentos, permanece em forma estática. Quando circula da matriz ou do documento que a contém para alguém que a vai receber - seja para dirimir dúvidas, seja para guiar a ação, seja para apoiar uma decisão, seja para preencher claros em relatórios ou documentos semelhantes, seja para estimular e possibilitar a especialização através do conhecimento teórico e da experiência prática - a informação assume forma dinâmica. Passa a ser uma espécie de centelha misteriosa, que provoca por parte do recipiendário as mais diferentes e imprevistas reações.

A informação, mesmo falsa, pode provocar efeitos concretos de grande vulto. Em 1938, Orson Wells, descrevendo através da radiodifusão uma invasão imaginária dos Estados Unidos por habitantes de Marte, causou pânico a milhares de pessoas, que deixaram suas habitações e suas cidades em fuga desordenada. (5)

Valeria a pena lembrar, igualmente, que em inglềs informação e dado são sinônimos perfeitos. Não há dúvida de que, mesmo em português, um dado é sempre uma informação. Advirta-se, porém, que em nosso idioma, quando usada no plural, a palavra dado geralmente se refere a informações quantitativas.

Registre-se, ainda, uma tendência geral, de natureza semântica, para distinguir informação de dado. O têrmo informação torna-se mais e mais inclusivo. Se qualquer dado é uma informação, nem tôdas as informações são dados. A informação pode ser uma equação algébrica, pode ser um organograma, um parecer jurídico, o conteúdo de uma carta, o texto de um relatório, o piscar de um farol, pode ser uma janela aberta ou fechada, enfim, pode ser qualquer sinal ou som, ou até mesmo a ausência de sinal ou som, segundo as convenções de um código prèviamente estabelecido. Constata-se, assim, que o conceito de informação é maís elástico e muito mais compreensivo do que o de dado.

O vocábulo informação é empregado freqüentemente, ora como sinônimo de documentação, ora como sinônimo de comunicação.

\section{DOCUMENTAÇÃO}

A exemplo do que ocorre com tantas outras, a palavra documentação tem passado por várias transformações semânticas. Até 1907, quando Paul Otlet a utilizou para rotular conjuntamente as atividades de biblioteca e as de arquivo, a palavra pertencia à terminalogia jurídica e nomeava, genèricamente, a certidão, o depoimento, o affidavit, os comprovantes - enfim, os documentos apresentados como prova nos litígios legais. ( $\left.{ }^{6}\right)$

A partir da nova interpretação de Otlet, o têrmo passou a designar o contrôle bibliográfico de tôda a produção literária dos diferentes países. Documentar, então, significava especialmente reunir documentos. Aí por volta de 1930 , a palavra começou a adquirir sentido mais lato. Já não significava o contrôle bibliográfico geral, mas designava os meios de utilização de literatura científica dentro de determinado campo especializado. (7)

Com base na inovação de Otlet, a Federação Internacional de Documentação. 
FID, adotou e mantém a definição seguinte: "documentar é reunir, classificar e distribuir informações de todos os gêneros sôbre todos os domínios da atividade humana". ( $\left.{ }^{8}\right)$ De acôrdo com essa definição oficial, as funções especificas dos serviços de documentação desdobram-se em três: reunião, classificação e distribuição de documentos. (9)

Em trabalho publicado em 1954, em Dortmund, o P r o f e s s o r alemão Erich Pietsch adicionou a essas funções as de normalizar, produzir, reproduzir e selecionar documentos. Outra autoridade na matéria, M. Verhoef, Diretor do Nederlands Instituut voor Documentatie en Registratuur (NIDER), além de não concordar que caiba também aos serviços de documentação a função de produzir documentos, considera as de reproduzilos e selecioná-los apenas como importantes auxiliares, não como funções es-
senciais.

A fim de explicitar integralmente a opinião de Verhoef, transcrevemos o trecho pertinente de seu trabalho:

"Não me parece que as outras atividades mencionadas pelo Professor Pietsch (normalização, produção e reprodução, seleção) devam ser consideradas funções do documentalista, nem do bibliotecário. Trata-se simplesmente de técnicas auxiliares que permitem melhorar o trabalho. A produção de documentos constitui, talvez, uma exceção, considerando-se as publicações secundárias (análises, revistas etc.) que são, de fato, subprodutos do trabalho dos documentalistas e dos

No Brasil, os serviços e institutos de documentação, todos surgidos nos últimos trinta anos, sobretudo depois da Segunda Guerra Mundial, dedicam-se por igual às funções de produzir, reproduzir, selecionar e às de reunir, classificar e
distribuir documentos.

Exemplos típicos são o Serviço de Documentação do DASP, criado em (11) 1941 (11), o Instituto Brasileiro de $\mathrm{Bi}$ bliografia e Documentação, criado em 1954 pelo Conselho Nacional de Pesquisa em colaboração com a Fundação Getúlio cumentação da Fundação Getúlio Vargas, criado em 1967. (13)

Como se sabe, essas três entidades compreendem bibliotecas, que desempenham as funções clássicas de reunir, ticularmente livros, periódicos e folhetos.
Ao mesmo tempo, as três são importantes produtoras, reprodutoras e selecionadoras de documentos. O Serviço de Documentação do DASP, além da Revista do Serviço Público, já publicou, entre livros e folhetos, centenas de títulos, perfazendo milhões de páginas. O IBBD, por sua vez, tem-se notabilizado sobretudo pela produção e reprodução de documentos, especialmente suas conhecidas séries de bibliografias.

O Instituto de Documentação da Fundação Getúlio Vargas compreende, entre suas dependências, o Serviço de Publicações, que hoje publica nove periódicos, inclusive um em inglês, além de já haver publicado mais de trezentos títulos de livros e folhetos. Acrescente-se que modernamente o têrmo "documentação" se emprega, também, no sentido de coleção impressa de documentos. As publicaçốes periódicas Documentation Economique, francesa, e Documentación Administrativa, espanhola, lançadas, a primeira em 1947, e da qual já se editaram 130 números, e a segunda em 1958, é da qual já se editaram 125 números, exemplificam essa variante de acepção.

De maneira que, tanto entre os especialistas que focalizam o assunto do ângulo teórico, quanto entre as práticas das instituições chamadas de documentação, persistem contradições e incertezas flagrantes sôbre o conceito de documentação.

Seja como fôr, o fato é que, hodiernamente, tôdas as formas de comunicação rápida de dados científicos, assim como as classificações cada vez mais complicadas, as listas de cabeçalhos de assuntos, os têrmos coordenados, as palavraschave, os descritores, o aumento de circulação de sinopses e sumários e, mais recentemente, a permuta assídua de artigos publicados em diferentes revistas que só se tornou possível graças aos modernos recursos reprográficos - tudo isso existe e se desenvolve sob o rótulo genérico e algo frouxo de documentação. Note-se, porém, que em nenhum caso a documentação perde a forma concreta. Livro, mapa, disco, fita magnética, cartão perfurado, álbum de fotografias, o documento é sempre algo tangivel, por assim dizer, o corpo habitado pela informação.

\section{COMUNICAÇÃO}

A palavra "comunicação", além de ser usada na linguagem imprecisa dos leigos, ora como sinônimo de documentação, ora 
como sinônimo de documento, ora como sinônimo de informação, tem ainda vários outros sentidos. $\mathrm{E}$, por assim dizer, uma palavra comprometida, cujo uso em textos especializados deve ser feito vigilantemente, a fim de evitar possíveis despistamentos indesejáveis do leitor.

Para os gramáticos, por exemplo, o substantivo "comunicaçã̃o" pertence às chamadas figuras de pensamento e tem significado particular.

"Comunicação: samento em que o orador dá a impressão de estar consultando os ouvintes, induzindo-os a oferecerem uma resposta favorável ao que defende.

Exemplo: Estudado o processo, certamente tendes vós um conceito exato da inocência do réu. Não 0 tendes?... As provas, porém, estão ao vosso alcance." (14)

Cabe-nos, assim, precisar o sentido especializado em que empregamos neste ensaio a palavra comunicação. Em última análise, comunicacão é o ato ou efeito de alguém transmitir fissicamente, de um país a outro, de um idioma a outro, de uma instituição a outra, ou mais comumente, de um indivíduo a outro, de maneira inteligível, uma informação ou uma série de informações.

Para que a comunicação se realize exemplarmente, é indispensável qu e além da transmissão e do recebimento físicos perfeitos e complexos, o seu conteúdo seja inteligível e signifique a mesma coisa tanto para quem a transmite, quanto para quem a recebe. Nas comunicações escritas, especialmente nas telecomunicações, faz-se necessário extremo cuidado, para que a mensagem transmitida seja captada sem qualquer alteração.

Um simples sinal de pontuação, como a vírgula, se deslocado, pode alterar e até inverter a mensagem. Casos de mensagem como estas: "Prudência, não matem" e "Prudência não, matem", ou "Tiraram, não está aqui" e "Tiraram não, está aqui", bastam para ilustrar a afirmativa.

Similarmente, a simples troca de uma letra é capaz de mudar, adulterar e até de inverter o sentido de qualquer informação comunicada. Por exemplo: "O livro foi escrito em linguagem exotérica", (exotérica com $\mathrm{x}$ ), quer dizer linguagem aberta à compreensão, acessível, fácil. Per contra: "O livro foi escrito em linguagem esotérica" (esotérica com s), quer dizer linguagem hermética, só compreensível para os iniciados.

O veículo ou dispositivo de que o emitente da informação se serve para transmiti-la, isto é, para comunicá-la ao usuário ou interessado, amigo ou inimigo, pouco importa.

Nos domínios da ciência, da administração e da vida prática, o que importa é sobretudo a integridade e a inteligibilidade da informação comunicada (transmitida e recebida). Cumpre que 0 "Tiraram, não está aqui" jamais seja recebido no outro extremo da cadeia de comunicação como "Tiraram não, está aqui".

\section{ADMINISTRAÇÃO}

Passemos agora ao segundo binômio do tema. Que é administração? Seria fácil, fácil, a qualquer estudioso familiarizado com a literatura pertinente, coligir uma lista opulenta, realmente muito longa, de definições do têrmo administração. Aqui, porém, são tão numerosas as definições conhecidas, tão entrelaçadas e até contraditórias, que, em vez de gerar esclarecimentos, a lista muito provàvelmente geraria confusão. Apenas para ilustrar, advirta-se que, na literatura, assim como na linguagem usual, administração é palavra freqüentemente empregada como sinônimo de govêrno, governança, superintendência, gerência, maneio, direção etc.

Parece-nos aconselhável, pois, fugir do cipoal intrincadíssimo das múltiplas definições de administração e, valendonos apenas de linguagem simples, isenta de qualquer prurido eruditista, dizer que administração é a ciência e arte de converter idéias, propósitos, desígnios, decisões, planos e projetos em realidades ordinàriamente, em realidades tangiveis.

A conversão de um propósito em uma realidade, especialmente se se trata de propósito de vulto, não se faz sem vencer múltiplas dificuldades, prever e afastar obstáculos, utilizar práticas testadas e preconizadas pela experiência universal. Em outras palavras: não se faz sem aplicar a arte e ciência da administração.

Demos a essa aplicação o nome de processo administrativo. o processo administrativo não se realiza de repente, de estalo, de chôfre, mas desenvolve-se em vários estágios, alguns simultâneos, outros consecutivos, os quais, embora complexos, já foram bem identificados e são bastante conhecidos. 


\section{ASSOMBROSOS FEITOS HUMANOS INDIVIDUAIS}

Nos domínios da literatura, da poesia, da música, da pintura, da escultura da arte em geral - há exemplos de assombrosos feitos humanos, pela qualidade e, também, pela quantidade.

Shakespeare, no periodo de apenas 22 anos, durante os quais exerceu várias outras atividades, inclusive a de ator secundário, escreveu sua obra composta de 38 peças teatrais (14 comédias, 11 tragédias, 13 histórias), além de 2 poemas narrativos, 21 poemas menores e 154 sonetos. O conjunto da obra de Shakespeare elevou-se e mantém-se na cumeeira da criação artística do mundo.

Pedro Calderón de La Barca escreveu 130 comédias, 80 autos sacramentais e um número não especificado de poesias.

Bach compôs, como já dissemos, 295 cantatas e 48 prelúdios e fugas, além de 7 missas a quatro vozes e orquestra, um número indeterminado de kyries, credos,
quartetos, solos, duetos, corais etc.

Goethe levou quase 60 anos, de 1774 a 1832, na composição do Fausto.

Beethoven foi outro trabalhador monstruoso, tendo deixado 9 sinfonias, 4 ouvertures, 7 concertos, 8 trios, 3 quintetos, 2 sextetos, 1 septeto, 2 missas, 1 ópera, 16 quartetos para instrumentos de corda, 38 sonatas para piano, 16 sonatas para piano com acompanhamento, 1 oratório, além de 138 outras composições
julgadas de menor importância.

Chopin, que viveu apenas 39 anos, compôs 21 valsas, 21 noturnos, 4 scherpos, 4 baladas, 26 prelúdios, 2 concertos para piano, 60 mazurcas, 16 polonesas, sem contar as inúmeras fantasias,
berceuses, barcarolas etc.

Balzac realizou a proeza de escrever, da Comédia Humana, que contém cêrca de 25.000 páginas, enreda e tange mais de 2.000 personagens.

Miguel Ângelo, trabalhando 16 horas por dia, grande parte do tempo deitado em posição ressupina, conseqüentemente incômoda para os seus movimentos, pintou a Capela Sistina, que é, em vulto e concepção, a maior obra de arte plástica jamais realizada por um único

Camilo Castelo Branco, talvez o escritor mais copioso da língua portuguêsa, escreveu mais de 200 obras, perfazendo
84 volumes.
Tolstoi dedicou 7 anos ininterruptos a redigir Guerra e Paz, considerado o maior romance até hoje produzido.

E para citar um artista vivo, outro monstro infatigável da arte, lembremos que Picasso, cujas telas lhe atestam a fôrça criadora pela qualidade e sucessão das fases, já pintou e espalhou pelo mundo milhares de quadros, sem falar no mural Guernica, tido como o apogeu da arte pictórica no século $\mathrm{XX}$. Além de pertencer ao grupo de pintores mais fecundos e longevos, Picasso apresenta plástico que, para assinar o nome completo, precisa de consultar um caderninho. Sabem qual é o nome completo de Picasso? Ei-lo: Pablo Diego José Francisco de Paula Juan Nepomuceno nidad Ruiz y Picasso la Santísima Tripanha, em 1881, o artista já conta 88 anos. E ainda pinta. E borda.

Êstes exemplos exponenciais e culminantes, em face dos quais todos os qualificativos se amesquinham, resultaram da fôrça criadora e do gênio de alguns artesãos intelectuais, categoria de que Balzac é, by far, o expoente máximo.

Quando, porém, descemos para a planície dos objetivos físicos, em que as obras e realizações humanas utilizam materiais corpóreos, como os metais, a madeira, as pedras, a terra, os equipamentos e outros da mesma natureza, nem mesmo o gênio isolado de Beethoven, ou o conjunto de gênios de todos os artistas acima citados, podem fazer algo. A única via conhecida e eficaz para levar a efeito grandes obras, como aquedutos, muralhas, barragens, arranha-céus, pontes, túneis, cidades, portos, canais, sistemas de navegação e de comunicação, é a via
administrativa.

A inteligência do homem até agora só inventou dois métodos para levar avante desígnios de grande vulto - a magia e a administração. Com efeito, no mundo quimérico dos contos de fadas, as coisas acontecem por milagre, de repente, surgem do nada, instantâneamente, graças ao poder de um anel, de uma lâmpada, de uma varinha de condão, ou de qualquer outro instrumento ou, disposi-
tivo.

\section{O PROCESSO ADMINISTRATIVO NO MUNDO DO MARAVILHOSO}

José Bento Monteiro Lobato que, como dewis Carrol, criou um mundo mágico de vastíssimas dimensões, inventou a 
fórmula do Faz-de-conta, utilizada especialmente pela famosa boneca de pano que virou gente, Emília, a favorita das crianças. Com o Pó de Pir-lim-pim-pim e o Faz-de-conta, os personagens das histórias infantis de Monteiro Lobato viajam no espaço e no tempo, para frente e para trás, movem montanhas, transportam cidades e países, tornam contemporâneas civilizaçốes e culturas històricamente separadas por milênios.

A título de ilustração de como as coisas são administradas no mundo encantado dos contos de fadas, basta citar a passagem seguinte de 0 Poço do Visconde:

"Pedrinho deu ordem à boneca para que cuidasse da lenha. Emília aplicou o Faz-de-conta, e num momento dez carros de boi começaram um vaivém contínuo do capoeirão até ali. Serviço rápido como o relâmpago.

- Pronto Pedrinho! Empilhei lenha até demais -523 metros cúbicos, segundo a nota que meus carreiros apresentaram, disse ela, dando a Pedrinho um papel com garranchos.

- Bom. Água e lenha já temos disse êle. Agora é preciso que você, $\mathrm{Na}-$ rizinho, se encarregue das casas e do barracão para as máquinas.

A menina também aplicou o Faz-deconta, de modo que num instante surgiu da terra um excelente barracão de madeira, com telhado de zinco, para as máquinas; e a cem metros dali, uma série de casas para operários, muito bonitas e higiênicas, tão bonitas que Pedrinho achou demais.

- Demais, não! - protestou ela. Quanto melhor acomodarmos nossos homens, melhor êles trabalham. Não concordo com o sistema de tratar os operários como se fôssem pedras insensiveis. As casinhas têm tudo dentro - até geladeira e rádio...

- E esta casa aqui? - perguntou Pedrinho, vendo uma distanciada da vila operária.

- Pois é aqui o escritório - o seu escritório, Pedrinho, já que é você o Superintendente do campo. E aquela mais pimposa, acolá, é o bangalô do perfurador que temos de mandar vir do estrangeiro.

- Muito bem, disse Pedrinho, tomando conta do escritório. Vou fazer o pedido das máquinas necessárias."

\section{O PROCESSO ADMINISTRATIVO NO MUNDO REAL}

Repita-se: a Administração é o único dispositivo ou método até hoje inventado pelo homem para realizar objetivos de vulto no mundo real.

Em verdade, quando se trata de levar a efeito objetivos de grande envergadura, a única via conhecida e eficaz é a Administração. Não há outra. Nunca houve outra.

No mundo real, no doloroso vale de lágrimas e de sombras em que vive o homem e a que se refere o Eclesiastes, de que outro meio dispõe o homem para realizar grandes desígnios?

Consideremos, por um momento, a construção do conjunto de Urubupungá, que compreende duas reprêsas gigantescas, ambas no trecho em que o rio Paraná divide o território de São Paulo do território de Mato Grosso, uma em Jupiá, já pràticamente concluída, a outra cêrca de $50 \mathrm{~km}$ acima, na Ilha Solteira, ainda em andamento. O Rio Paraná, no referido trecho, escoa-se ao longo de um leito de $2 \mathrm{~km}$ de largura, o que dá as dimensões das reprêsas. Empreendimentos dêsse jaez demandam uma combinação específica de múltiplos meios corpóreos e incorpóreos e sua utilização racional, segundo planos bem estruturados. Conhecimentos teóricos de vária natureza, capacidade profissional de dezenas de tipos, recursos financeiros astronômicos, equipamentos variados e complexos, meios de transporte, mãode-obra qualificada, mão-de-obra nãoqualificada, instalações, os mais diversificados materiais etc., etc., tudo isso é combinado e transformado nas reprêsas, nas casas de máquinas, compondo, afinal, as usinas hidrelétricas que ali se estão construindo.

Daí o reconhecimento tardio, muito tardio, que os cientistas sociais, notadamente os sociólogos, hoje fazem da importância da Administração. Sabe-se que - managerialismo desenvolvido pelos americanos habilitou os Estados Unidos a exercer sôbre a Europa uma nova espécie de imperialismo, a que se pode chamar imperialismo administrativo.

Em discurso pronunciado no dia 24 de fevereiro de 1967, em Jackson, Mississipi, sob o título Os três fossos, Robert S. MacNamara, um dos maiores ases da Administração moderna, acentuou que o fôsso existente entre a Europa e os 
Estados Unidos não deve ser chamado technological gap, porém managerial gap. E acrescentou que a corrida dos cientistas e técnicos para os Estados Unidos não é determinada meramente porque "nós estamos mais avançados em matéria de Tecnologia, mas porque, em vez disso, nós temos uma administração mais moderna e eficiente".

"Deus - disse MacNamara - é claramente democrata. Êle distribui capacidade cerebral (brain power) por tôda parte."

Mas, muito justificadamente, Êle espera que façamos alguma coisa eficiente e construtiva com êste dom incomparável. Isso é a missão precipua da administração (That is what management is all about).

A administração, em última análise, é a mais criativa de tôdas as artes, pois seu instrumento é o próprio talento humano.

Qual é, afinal de contas, a suprema tarefa da administração?

\section{E tratar das mudanças.}

A administração é a porta através da qual as mudanças sociais, políticas, econômicas, tecnológicas - em suma, as mudanças em tôdas as dimensões - são racional e efetivamente introduzidas e disseminadas na sociedade." (16)

Se os americanos têm progredido econômicamente em ritmo mais acelerado, chegando a criar o país mais poderoso e mais desenvolvido do mundo, aquêle cujo produto interno bruto (PIB) per capita é também o mais alto, isso aconteceu, segundo MacNamara, porque os americanos dão o devido valor à Administração. Compreendem êles, coletivamente, a imensa, a tremenda fecundidade social da Administração, como mico e social. (17)

Ao primeiro exame, logo percebe o observador, até intuitivamente, que a informação desempenha o papel de fluido vital que lubrifica, limpa e protege os chamados canais competentes de todo o mecanismo administrativo.

Desde o momento em que um detentor do poder de decidir fixa uma política, até o momento em que a política interpretada, planejada e canalizada para a realidade se transforma em uma estrada de ferro, ou em uma capital, em uma campanha de alfabetização, ou em uma rêde de portos e canais, ou em um centro de processamento automático de dados, é indispensável a existência de uma corrente contínua de informaçốes idôneas, precisas e exatas. Para que o processo administrativo se desenvolva e se complete exemplarmente, extraindo - máximo de resultados dos meios investidos, uma de duas: ou o administrador tem acesso rápido e regular a fontes de informações fidedignas, atualizadas e completas, ou possui uma bola mágica de cristal.

Examinemos, agora, ainda que sumàriamente, 0 papel desempenhado pela informação ao longo do processo administrativo. Consideremos em primeiro lugar a fixação da política, isto é, a decisão ampla, clara e definitiva de realizar tal ou qual obra, ou resolver tal ou qual problema.

Ocorre que em todos países, particularmente nos subdesenvolvidos, sempre há mais problemas pendentes de solução do que recursos para enfrentálos. Impõe-se, assim, o estabelecimento de uma rigorosa escala de prioridade. Em se tratando do Brasil, cujo produto interno bruto (PIB) per capita é cêrca de 15 vêzes inferior ao dos Estados Unidos, é notório o desequilíbrio colossal existente entre o número de problemas cruciais e o montante de recursos técnicos, financeiros e outros.

Aliás, muitos problemas brasileiros, como o do transporte e o da alfabetização geral, deveriam ter sido resolvidos pelas gerações passadas, como ocorreu na Argentina. Seja como fôr, os governos federal, estaduais e municipais do Brasil não estão capacitados, sobretudo por escassez de recursos financeiros e knowhow, para atacar simultâneamente todos os problemas pendentes de solução. Cumpre-lhes organizar a lista de prioridades, a que já me referi, a fim de enfrentar em primeiro lugar os problemas mais agudos. Pois bem, para que os dirigentes do país possam identificar os problemas mais agudos, é preciso que disponham de amplos mananciais de dados e informações. Identificar, analisar e sopesar as vantagens e desvantagens de cada solução aventada para cada problema e, finalmente, optar pelas soluções suscetíveis de trazer o maior bem ao maior número, é tarefa que sòmente se consegue realizar à luz de informaçốes completas e verdadeiras. Em Ciência Política, o critério em que o go- 
vernante se deve basear para estabelecer a escala de prioridade é o chamado critério da máxima conveniência social ou, em certos casos, o seu reverso, o critério do mínimo sacrifício coletivo. (18)

Há homens públicos inegàvelmente dotados de poderosa intuição. Winston Churchill, sem dúvida a maior figura histórica até agora surgida no século $\mathrm{XX}$, era dotado de intuições que tangenciavam pelo poder divinatório. Foi êle que previu o perigo letal que o nazismo alemão representava para o mundo democrático, e sua previsão foi anunciada antes de Hitler assumir o poder na Alemanha e prepará-la para a Segunda Guerra Mundial. Terminada a guerra quente, foi êle que previu e denunciou o advento da chamada guerra fria.

Figuras históricas extraordinárias, como José do Egito, Alexandre, o Grande, Joana D'Arc, Napoleão Bonaparte e Winston Churchill são como meteoritos humanos: só de raro em raro riscam os céus da História. No seu dia a dia, a Administração não pode nem deve contar com êsses vultos culminantes que, de quando em quando, aparecem e iluminam ou abalam as respectivas épocas. A Administração tem que ater-se realisticamente às possibilidades de contar com pessoas normais: menos brilhantes êstes, mais talentosos aquêles, mas de qualquer maneira situados na faixa dos indivíduos encontráveis - dos disponíveis. Assim sendo, à míngua de inteligência peregrina e de intuições prodigiosas, as emprêsas públicas e particulares têm que entregar a sua administração a homens mais ou menos comuns, embora seja preferível entregá-la a sêres dotados de poderosa inteligência e de outros dotes intelectuais e morais.

Eis por que o papel da informação no processo administrativo é tão importante que seria difícil de exagerar.

Para se estabelecer uma escala de prioridade, para graduar o pêso dos problemas que assoberbam o País, ou determinado Estado, ou determinado Município, o detentor do poder necessita da assistência da informação tanto quanto seus pulmões necessitam da existência do ar.

Embora haja pessoas com aptidões mais acentuadas para as funções executivas, pessoas que pensam claramente, que analisam realisticamente os fatos e, portanto, são capazes de fazer opções judiciosas, não é sustentável a tese de que haja administradores natos.
O autor da Decadência do Ocidente, o controvertido filósofo alemão Oswald Spengler, esposou a tese de que "há homens que nascem para mandar, assim como há outros que nascem para obedecer", chegando assim a admitir o ponto de vista de que, como o poeta, o bom administrador nasce. (19) A proposição de Spengler foi, entretanto, desmoralizada pelo criador do scientific management, Frederick Winslow Taylor, quando, no primeiro capítulo da obra Principles of Scientific Management, publicada em 1911, afirmou que o administrador se faz, como qualquer outro profissional. Na opinião de Taylor, não há administrador nato, por mais bem dotado, que possa competir vantajosamente com um grupo de homens comuns, associados em tôrno de um propósito e agindo sistemàticamente. (20)

"Agir sistemàticamente" é outra maneira de dizer "agir de acôrdo com o conhecimento objetivo dos fenômenos envolvidos". Ora, não é possível haver conhecimento objetivo, a não ser por intermédio da informação. O próprio conhecimento, que é aperfeiçoado por meio de pesquisas e experiências, não deixa de ser um produto da informação residual acumulada, a pouco e pouco, e resultante de cada pesquisa e de cada experiência. Logo, quando alguém fixa uma politica e o faz clarividentemente, é porque recolheu, analisou e apurou todos os fatos e informações pertinentes.

\section{FIXAÇÃO DO OBJETIVO}

Simulemos uma aplicação do processo administrativo ao problema do alargamento da Praia de Copacabana, que é, por enquanto, apenas uma obra em andamento. Quando fôr transformada em realidade física, a Praia de Copacabana terá avançado pelo mar adentro, tomando-lhe 300 a 400 metros, e assim permitindo a abertura de pistas de automóveis, a construção de parques infantis e postos de estacionamento, a localização de centros de exposição, de restaurantes e boites etc.

A realização dessa obra terá que passar, necessàriamente, pelo processo administrativo. Este começou pela decisão de executar a obra, fase chamada fixação da política. A fase seguinte foi a do planejamento. A medida que o planejamento se tornou mais e mais preciso e específico, o processo administrativo 
passou à fase da projetação. Terminada esta, foi iniciada a fase da execução. Durante a execução, duas outras fases estão presentes: a da coordenação e a do contrôle. Desde a fixação da politica, até a conclusão da obra, sua inauguração e entrega ao público, será imprescindivel a existência de uma direção.

Dirigir é a tarefa complexa de optar por esta ou aquela solução e expedir, pelos meios competentes, oralmente ou por escrito, as ordens ou instruções para que tais e tais conseqüências sejam obtidas. O exercício da direção pressupõe a posse de autoridade. Em linguagem administrativa, autoridade vem a ser o direito de decidir e mandar e o poder de se. fazer obedecer. (21)

\section{PLANEJAMENTO}

Uma vez estabelecida uma política, sua execução passa a depender mais e mais de novas informações. A fase que se segue à fixação da política, já o dissemos, é a do planejamento. Que vem a ser planejar? Planejar é decidir que fazer, quando fazer e onde fazer. Aqui também o administrador se vê a braços com a impossibilidade de responder sàbiamente a estas perguntas, se desconhece os fatos pertinentes. Suponhamos que, sopesando os vários problemas pendentes de solução em determinado momento, o detentor do poder opte pela criação de novas universidades e pela ampliação das universidades existentes. Problemas concorrentes, que poderiam existir, como a construção de rodovias, a ampliação da rêde hospitalar, o fomento da agricultura, a construção de navios mercantes, e outros, são assim preteridos em favor da politica de construir e ampliar universidades. E de evidência transparente que tal decisão sòmente pode ser considerada racional se todos os fatos pertinentes, todos os prós e contras, tôdas as vantagens e desvantagens relativas aos outros problemas forem comparativamente analisadas e constatadas. Essa análise e verificação dependem, sem dúvida, de acuidade mental. Não podem ser feitas sem competência profissional. Mas, o exercício da acuidade mental e a aplicação da competência profissional exigem, no caso, um fundo de informações idôneas.

E como responder a segunda pergunta, isto é, onde construir as novas universidades e quais das existentes deverão ser ampliadas? Para simplificar a argumen- tação, pensemos apenas na primeira universidade. Onde localizá-la? Em Bauru, em Manaus, na Ilha do Bananal, em Montes Claros, na Praia do Pinto, em Joinville?

Salta à vista que, para ser judiciosa e certa, a escolha do local depende de tôda uma série de informações que permitam comparações de necessidade e recursos, a fim de que a universidade se localize onde possa fazer o maior bem ao maior número.

Não basta, entretanto, decidir o que fazer e escolher o local da obra. Um plano só se completa quando se decide também quando fazer, isto é, quando a decisão é cronogramada e jungida a um calendário. A duração do trabalho administrativo para realizar a obra - no caso, a universidade - pode ser de três anos, cinco anos, dez anos, quinze anos, e até mais. Também esta decisão não pode ser tomada por palpite, nem deve depender da duração de mandatos políticos.

A fixação do período de tempo em que a obra deva ser executada há de ser feita à luz de dados e informações objetivas. Não sòmente é mister determinar a duração da obra em têrmos de meses ou de anos, senão também estabelecer o calendário ou cronograma, isto é, a lista das datas do início e da conclusão, bem como das etapas intermediárias.

Tratando-se, por exemplo, da construção de uma usina hidrelétrica, o calendário deve indicar precisamente o dia, mês e ano de cada uma das etapas: a projetação, o início, o canteiro de obras, a barragem, a ensecadeira, a construção da casa de máquina, a aquisição e recebimento da aparelhagem, a instalação das turbinas, o fechamento da barragem, a contrução da linha de distribuição, a conclusão, os ajustamentos finais e a inauguração.

Que administradores e engenheiros poderiam marcar as referidas datas à revelia de variados e complexos estudos preliminares, sem dispor dos dados e informações para servir de lastro ao estabelecimento do calendário?

Coloquemo-nos agora junto aos dirigentes da obra, dos que vão expedir ordens para que as coisas se façam, desde a obtenção do financiamento, a aquisição de material, a contratação de pessoal e a execução pròpriamente dita das etapas já enumeradas. Como seria possi- 
vel dirigir centenas ou milhares de pessoas - engenheiros, economistas, advogados, contadores, mecânicos, taquígrafos, datilógrafos e simples trabalhadores braçais - sem receber, em corrente contínua, grande quantidade de relatórios verbais e escritos, que são outras tantas informações sôbre o que está ocorrendo em cada setor, tanto no que se refere ao equipamento, quanto no que se refere ao comportamento dos dirigentes intermediários e seus subordinados?

É óbvio que, em tôdas as fases do processo administrativo, a informação correta e oportuna desempenha o papel, a que já me referi, de fluido vital, que lubrifica e propicia o funcionamento dos chamados canais competentes.

Em nenhuma fase, porém, mais do que na fase difusa da direção, que se desenvolve paralelamente a tôdas as outras fases, e cujo cronograma se estende do princípio ao fim da execução da obra planejada, é a informação mais necessária.

O grupo de administradores e dirigentes que detenha o poder de tomar decisões finais, retificar decisões já tomadas, enfim, conduzir e combinar todos os elementos engajados na e para a execução da obra, ver-se-ia desorientado, confuso, exposto a conflitos internos, se não recebesse, com a maior regularidade possível, as informações necessárias para tomar decisões tempestivas e racionais.

O observador agudo que se colocasse no local de trabalho dos dirigentes, em situação de poder testemunhar a dinâmică, às vêzes dramática e até mesmo patética, do processo decisório, não teria dificuldade alguma em perceber como é crucial o papel que a informação desempenha como apoio da ação administrativa. Não há exagêro em asseverar-se que a ação administrativa normal - e normal, aqui, deve ser entendido como antônimo de patológico - se desenvolve em todos os momentos, e sob tôdas as circunstâncias, alicerçadas no conhecimento das realidades ambientes, o que pressupõe um fluxo regular de informações.

\section{COORDENAÇÃO}

A coordenação, conquanto possa e, em alguns casos, deva ser delegada, é função específica dos órgãos dirigentes. Coordenar significa unir os esforços das pessoas engajadas na execução da obra, de maneira que êles se somem, se fundam uns nos outros, movendo-se todos na mesma direção, uns complementando os outros, de tal modo que o resultado final se converta na obra desejada. Não havendo coordenação, ainda que tôdas as pessoas associadas no trabalho sejam, cada uma delas, a mais competente na respectiva especialização, e que todos os equipamentos sejam os mais adequados, a obra não será executada, os esforços não se ajustarão uns aos outros, haverá desperdícios clamorosos, enfim, a emprêsa se transformará em pandemônio.

O exemplo mais convincente de que a ausência de coordenação provoca o colapso catastrófico do esfôrço conjunto, encontramo-lo no Velho Testamento: é a Tôrre de Babel. Diz a Bíblia que, valendo-se do recurso de misturar-lhes os idiomas, Jeová tornou impossivel o entendimento entre os homens ocupados na ereção da Tôrre de Babel. O que uns diziam não era entendido pelos demais e vice-versa. A coordenação, ipso facto, tornou-se impossível. Nesse caso, qual o fator que provocou a confusão, a frustração geral e a debandada anárquica dos homens? A resposta surge com a naturalidade da água, que desliza do nível mais alto para o mais baixo: a ausência de informação. Seria ocioso e mesmo enfadonho, equivaleria a arrombar porta aberta, insistir na demonstração de que a fase administrativa que se chama coordenação depende medularmente da presença daquele fator, ou fluido vital, que é a informação.

\section{CONTRÔLE}

Ao desenvolver-se o processo administrativo, para que logre o fim escolhido, isto é, para que produza a obra desejada - seja ela uma catedral ou uma ponte, um lago artificial ou um viaduto nã̉o basta que o planejamento, a projetação, a direção e a coordenação se revelem idôneos. A fase complementar do contrôle é indispensável. Administrativamente falando, controlar é verificar se as ordens expedidas foram corretamente cumpridas, em última palavra, é confrontar o planejado com o executado ou com o que se esteja executando.

f́ por meio do contrôle que o administrador protege a obra em andamento contra atrasos, acelerações injustificadas, desvios ou redefinições dos planos estabelecidos. 
Quando exercido concomitantemente, o contrôle habilita o administrador a identificar no momento exato, às vêzes em flagrante, qualquer das anomalias referidas. O atraso de um setor, que pode refletir-se na marcha de outro, a aceleração desassisada de uma etapa, cuja terminação antes da hora conveniente pode causar prejuízo, os desvios de esforcos que, em vez de produzirem o resultado $\mathrm{A}$, esperado, produzem o resultado $\mathrm{M}$, inútil ou contrário ao objetivo final, e as redefinições de partes do plano primitivo, feitas por defeito de linguagem, ou de informação, ou por qualquer outra causa, tudo isso o administrador pode evitar ou corrigir, mediante o exercício correto do contrôle.

Descrito assim, por meio de exemplos e em linguagem simples, o que vem a ser o contrôle no processo administrativo, podemos agora inquirir: acaso seria possível ao administrador, ainda que se tratasse de pessoa excepcionalmente dotada de perspicácia, inteligência, memória, energia e coragem, exercitar a função de controlar, sem se valer ininterruptamente de informações?

Quem se abalançaria a responder pela afirmativa? É claro, é curial, é intuitivo que a fase administrativa do contrôle depende tanto da informação quanto a fase da coordenação, já estudada.

\section{A INFORMAÇÃO - IMPULSOR \\ DA ADMINISTRAÇÃO}

Inclinamo-nos a crer que as considerações, fatos e argumentos até aqui apresentados são suficientes para demonstrar a validade da tese: a informação, como apoio da ação administrativa, desempenha simultâneamente o papel de impulsor e guia do administrador.

Ao contrário do poeta, que manipula quimeras, que recebe inspiração de sonhos e doces fantasias, o administrador deve ser um realista impenitente. E-lhe forçoso buscar e aceitar as realidades em meio às quais desenvolve sua ação. Ainda que essas realidades sejam prosaicas, ou ásperas, ou vulnerantes, ou mesmo repulsivas, o administrador não deve recorrer ao artifício da fuga psicológica para amenizar sua contingência. preciso não só enfrentar as realidades, senão também diligenciar por conhecêlas a fundo, em todos os seus meandros e escaninhos, por mais sutis, enganosos ou fugidios que sejam. E, para se apos- sar das realidades, agir e reagir sempre em função delas, não resta ao administrador outro caminho senão o da pesquisa. Seria redundante acrescentar que o resultado da pesquisa, em última análise, é sempre uma informação, ou um conjunto de informações.

Uma tese é uma proposição que se apresenta para ser defendida, no caso de ser refutada. Não creio que o candidato à defesa da tese para conquistar, por exemplo, um prêmio, um cargo ou um título universitário, revelasse acuidade intelectual e boa orientação, se escolhesse - presente tema A Informação como Apoio da Ação Administrativa. Seria fácil demais defender essa tese. O candidato correria o risco de ser reprovado por escolher uma tese que se comprova pelo próprio enunciado.

Até aqui discorremos de maneira genérica sôbre o papel que cabe à informação como alicerce, fonte, impulso e guia da ação administrativa. Não fizemos qualquer referência, entretanto, à espécie ou às espécies de informação que concorrem para servir de apoio à ação administrativa.

\section{QUE ESPÉCIE DE INFORMAÇÃO IMPULSIONA E GUIA O PROCESSO ADMINISTRATIVO?}

Recorrendo ao método socrático de argumentar por meio de perguntas e respostas, indaguemos agora: que espécie de informação possui as virtudes de contribuir para tornar fluente, sábia e racional a ação administrativa?

A resposta a esta pergunta é condicionada à índole do objetivo que o administrador esteja tentando realizar. Em freqüentes casos, a informação será especializada, e sòmente determinados especialistas poderão prestá-la. Em outros casos, ou em certos momentos do processo administrativo, a informação pode ser factual. Há instâncias em que a informação poderá ser simplesmente remissão a um dispositivo legal, regulamentar ou regimental.

Em suma, os mais distintos tipos de informações, qualitativas e quantitativas, doutrinárias e rotineiras, confidenciais ou notórias têm guarida no processo administrativo, dependendo a sua natureza da fase a que se referir, do objetivo a ser alcançado, do maior ou menor grau de competência do sadministrador. 
A formação profissional do coletor, elaborador, processador, e prestador de informaçốes ao dirigente de uma emprêsa particular, ou ao titular do problema que estiver em jôgo, varia segundo a fase do processo administrativo que estiver em andamento. Amiúde, a informação terá que ser coligida, elaborada e prestada por assessôres especializados, que não se enquadram nem na categoria dos bibliotecários, nem na categoria dos documentalistas, nem na categoria dos futuros informatas.

Os assessôres de um Chefe de Estado, por exemplo, terão que recorrer inevitàvelmente, ora ao bibliotecário, ora ao estatístico, ora ao economista, ora ao jurista, ora ao documentarista, para reunir os dados e informações necessários ao esclarecimento das várias facêtas de determinado problema.

As vantagens e desvantagens, os prós e contras de cada solução proposta ou indicada para cada problema terão que ser esmiuçados, verificados e reverificados. Os conselhos dos assessôres de um Chefe de Estado precisam reunir pelo menos três qualidades: fidedignidade, idoneidade profissional ou científica e capacidade de globalização. Por capacidade de globalização ou macroanálise deve entender-se a situação em que todos os elementos pertinentes à análise do problema são levados em conta. Em outras palavras, as informações compatíveis com o nível de autoridade de um Chefe de Estado devem ser verdadeiras, completas, precisas, não raro exaustivas.

Vê-se, pois, que os informantes aí necessitam do concurso de outros informantes especializados, cada um complementando ou esclarecendo o conjunto de dados ou informações prestados pelos demais.

A interpretação compete aos que, além de possuírem capacidade de nível superior para desempenhar as funções de assessor de Chefe de Estado, também se encontram em situação de merecer a confiança do assessorado.

Prevê-se que, em futuro muito próximo, talvez aí por volta do ano de 1980 , a revolução da informação exercerá influência muito maior no processo administrativo, opulentando a instrumentalidade do administrador com recursos que atualmente mais parecem sonhos fantásticos do que probabilidades surgentes.

\section{O FUTURO DA INFORMAÇÃO} ADMINISTRATIVA

Em conferência por mim pronunciada durante a Semana da Reforma Administrativa, no Museu de Arte Moderna, e a que dei o título algo prospectivo de o Futuro "Estatelante" da Documentação Administrativa, salientei e exemplifiquei as mudanças radicais - algumas tão inusitadas, que chegam a ser inimagináveis - por que passará a ciência e arte da Administraçấo em conseqüência daquilo que os futurólogos denominaram a revolução da informação.

São dessas conferências os parágrafos seguintes, que me permito transcrever, porque não tenho motivos para verbalizá-los aqui de maneira diferente:

A utilização prevista e crescente de computadores eletrônicos no processamento de dados e informacões prenuncia mudança absolutamente revolucionária na arte e ciência da Administração. Exemplo recente disso tem-se no efeito que os centros de processamento de dados fiscais produziram sôbre o contribuinte americano. Segundo fontes oficiais, a simples notícia de que o Serviço das Rendas Internas dos Estados Unidos iniciara, primeiro em Atlanta, Capital do Estado de Georgia e, depois, em Martinsbourg, West Virginia, a 70 quilômetros de Washington, o escrutínio eletrônico das declarações do Impôsto de Renda, determinou imediatamente aumento considerável da arrecadação respectiva.

Prevê-se para o futuro próximo que o risco de sonegar ou evadir impostos será tão grande nos Estados Unidos, que ninguém, nenhum contribuinte, por ingênuo que seja, tentará conscientemente enfrentálo. As informações sôbre as rendas auferidas por qualquer contribuinte e provenientes de tôdas as fontes possíveis, salários, dividendos, aluguéis, participação em lucro, juros, donativos etc., não importa se cada uma das rendas proceda de regiões ou Estados diferentes, acabarão por ser eletrônicamente identificadas e reunidas sob um número inconfundível, correspondente ao contribuinte e constante do cadastro fiscal. 
Em futuro mais remoto, entre o ano 1980, e o ano 2000, será possivel a existência de arquivos únicos ou centros nacionais de informações, que contenham, em relação a cada habitante do país, dados completos e atualizados. As características biológicas e jurídico-sociais, assim como os tributos a que esteja sujeito, a situação legal, os antecedentes, a atuação relativamente à segurança nacional, a ficha médica, a carreira profissional, os empregos ocupados, o crédito bancário, tudo isso e muito mais.

A documentação que, por êsses avanços tecnológicos, poderá ser reunida, mantida e atualizada em centros administrados e controlados pelo poder público e, conseqüentemente, acessiveis às autoridades policiais, fiscais e outras, provocará, sem dúvida alguma, tremendas e imprevisíveis mudanças nas relações entre governantes e governados.

O método da amostragem, que já permite ao especialista em sondagens da opinião pública apurar resultados fidedignos, como os que há vários anos se fazem em muitos países para prever os resultados de eleições, conjugado aos recursos modernos de processamento instantâneo de dados e informações, desvendará os mistérios dos problemas sociais, identificará suas correlações sutis, porá a descoberto as relações de causa e efeito, em suma, oferecerá aos governos o conhecimento imediato e seguro do que esteja acontecendo nos respectivos países.

E então, como predizem Herman Kahn e Anthony J. Wiener, a nau do Estado esta cediça metáfora, que ora assume nova significação - passará a ser dirigida exatamente como hoje o motorista dirige automóveis (22). Tôdas as fases do processo administrativo poderão ser incrìvelmente aceleradas e cada uma delas lastreada por informações captadas, processadas e interpretadas com a velocidade do computador, que é igual à velocidade da luz $-300.000 \mathrm{~km}$ por segundo.

Isto não é profecia, muito menos adivinhação. E uma das chamadas "extrapolações tecnológicas" ou "conjecturas sistemáticas", a que recorrera os homens algo mitológicos do Hudson Institute, para criar aquilo a que deram o ambicioso nome de "Nova Ciência" - a Futurologia.

Como em cada país a entidade mais poderosa é precisamente - 0 govêrno, seria ingenuidade pensar que os governantes desprezarão ou negligenciarão as conquistas modernas que hoje, apesar de tão complexas e tão numerosas, se acomodam sob o rótulo criado pelo francês Philippe Dreyfus - Informática.

\section{NOTAS}

(1) BfBLtA. V. T. - Exodus. Capitulo 13, versiculos 21-22. In: Bíblia. Bíblia de Jerusalém. Paris, Desclée de Brouwer, 1955, pág. 97.

(2) ENCICLOPEDIA Italiana di Scienze, Lettere ed. Arti. Roma, Instituto della Enciclopedia Itallana, 1935-13. v. 26, pág. 249.

(3) ENCYCLOPAEDIA Britannica. Chicago. Encyclopaedia Britannica Inc., 1968 , v. 6, p.
260 p.

(4) Comunicaçăo pessoal.

(5) HAYAKAWA, S. I. A linguagem no pensamento e na açắo. Săo Paulo, Enio Matheus Guazelli, 1940, pág. 21. HAYAKAWA cita duas obras que tratam do fato: Hadley, Cantril. A invasão de Marte. Princeton University Press, 1940, e Houseman, John. Os homens de Marte, Harper's Magazine. dez. 1948.

(6) BJORKBOM, Carl. The History of the word documentation within the FID. Revue de la Documentation. $26(3): 68,1959$.

(7) BJORKBOM, Carl. - op. Cit.

(8) BJORKBOM, Carl. - Op. Cit.

(9) VERHOEF, M. - Bibliothèconomie et Documentation. Bulletin de l'UNESCo à l'intention des bibliothéques. 15 (5): 205-208214, Sep. Oct., 1960.

(10) VERHOEF, M. - Op. Cit.

(11) BRASIL. Departamento Administrativo do Pessoal Civil. Serviço de Documentação. Regimento do D.A.S.P. aprovado pelo Decreto n. ${ }^{\circ} 50.679$, de 31 de maio de 1961 . Rio de Janeiro, Departamento de Imprensa Nacional, 1961. Artigos 61-70.

(12) BRASIL. Leis, decretos etc. Decreto número 35.430 - 29 abr. 1954 , artigos $2 .^{\circ}$ e $4 .^{\circ}$. In: - Instituto Brasileiro de Bibliografia e Documentação. Rio de Janeiro, IBBD, 1954. págs. 6-7.

(13) FUNDAÇÃO GETƯLIO VARGAS. Relatório Anual do exercício de 1968. Rio de Janeiro, Fundação Getúlio Vargas, 1969 , pág. 113.

(14) VIEIRA, Antenor. Nova Enciclopédia da Lingua Portuguêsa. Rio de Janeiro, Livros do Brasil, s/data, vol. 6 , pág. 58

(15) MONTEIRO LOBATO, José Bento. o poço do Visconde. São Paulo, Ed. Brasiliense, 1958. págs. 100-101.

(16) McNAMARA, Robert S. The Three gaps. Vital Speeches. 33: 357-361, April 1, 1967.

(17) MCNAMARA, Robert S. - op. Cit.

(18) DALTON, Hugh. Princípios de finanças públicas. Río de Janeiro, Fundação Getủlio Vargas. 1960 . págs. $7-13,155,156,157$.

(19) SPLENGER, O. - o homem e a técnica. Trad. de Érico Verissimo. Pôrto Alegre, Ediçóes Meridiana, 1941. págs. 90-91.

(20) TAYLOR, Frederick Winslow. The principles of scientific management. New York. W. W. Norton, 1967. pág. 6 .

(21) FAYOL, Henri. Administration industrielle et générale. Paris, Dunod, 1950, pág. 21.

(22) KAHN, Herman \& WIENER, Anthony J. The Year 2000. New York, Macnlillan, 1968. pág. 96 . 